\title{
Molecular detection of the causative agent of the potato soft rot, Pectobacterium carotovorum, in Egypt and essential oils as a potential safe tool for its management
}

\author{
Mohamed Hamed El-habbak ${ }^{1}$ and Mohamed Hassan Refaat ${ }^{2,3^{*}}$
}

\begin{abstract}
Forty-two bacterial isolates were collected from soft-rotted potato tubers originating from four governorates in Egypt. Their phenotypic and genetic characteristics were studied. The phenotypic identification resulted in grouping the studied isolates into five different species and/or genera including Pectobacterium sp., Bacillus sp., Dickeya sp., Pseudomonas sp. (1), and Pseudomonas sp. (2). The molecular identification of the 10 isolates of them were pathogenic to potato tubers and other hosts. More specific identification of the later 10 isolates, using two specific primers for P. carotovorum subsp. carotovorum (Pcc) and the reference strain PccY46 (Acc. No. KP187511.1), revealed that all these isolates had yielded 220-272-bp DNA fragments identical to the 16S rRNA gene of PccY46. Phylogenetic analysis showed sequence similarity ranging from 87 to $98 \%$, which confirmed the genetic variation among the 10 tested strains of Pcc. The isolates were distributed in four major clusters, each subdivided into a few sub-clusters. In another experiment, two different essential oils (peppermint and clove oils) plus a nano-Cu-based fungicide $\left(T_{a n g}{ }^{\circledast}\right)$, in comparison to the two different antibiotics and the two copper fungicides, were evaluated for their potential management on the three most severe bacterial isolates (Pcc1, Pcc5, and Pcc10). Results of in vivo experiment showed that clove oil was the most effective, where it caused a reduction of disease severity $(0$. $0 \%)$ on potato tubers, 4 days post artificial inoculation.
\end{abstract}

Keywords: Pectobacterium carotovorum, Molecular detection, Essential oil, Nano-cu, Safe control, Potato

\section{Background}

In terms of food crops such as rice (Oryza sativa L.), maize (Zea mays L.), and wheat (Triticum aestivum L.), potato (Solanum tuberosum) has so far been ranked fourth in the world, and regarding its remarkable nutritive value, its total world acreage gets far beyond any other cultivated crop (Douches et al. 1996).

In 2016, Egypt was ranked 14th in the world, with 5.0 million tons of potatoes produced (FAO 2016). The blackening of potato tuber in field and the tuber soft rot in storage, transit, and field are all caused by

\footnotetext{
* Correspondence: Mohamed.refaat@fagr.bu.edu.eg

${ }^{2}$ Genetics and Genetic Engineering Department, Faculty of Agriculture at Moshtohor, Benha University, Moshtohor, Tukh, Qalubia 13736, Egypt

${ }^{3}$ Moshtohor Research Park, Molecular Biology Lab, Benha University, Tukh, Qalubia 13736, Egypt

Full list of author information is available at the end of the article
}

Pectobacterium carotovorum subsp. carotovorum (Pcc), which causes a great loss (Nabhan et al. 2011). Perombelon and Kelman (1980) referred the main causes of tuber bacterial soft rot to either unsuitable environmental conditions during growth or a bad storage state or to both. Among the members of the species Pectobacterium, which infect a wide range of vegetable crop hosts, Pectobacterium atrospeticum was identified as the main potato pathogen (Gardan et al. 2003).

Many strains of Pectobacterium atrosepticum have been subjected to genetic analyses, which suggested that almost all were, to a great extent, quite close to the other species, Pectobacterium atrosepticum (Avrova et al. 2002). Ma et al. (2007) reported that despite the close resemblance, any good reason(s) to explain how the Pectobacterium spp. members uniquely infect different 
vegetable crops still has not been genetically figured out yet.

Controlling bacterial potato bacterial soft rot is a real challenge for producers. Many control strategies have been developed and applied. Using, for example, protective chemicals make ware tubers unsafe for consumption. In addition, Crépin et al. (2012) stated that although biological control techniques have recently progressed so far to control to some extent disease severity, they argued that their use, however, is still limited. Though certified, tubers are subject to the occurrence of soft rot during later tuber handling, which leads to severe disease infection loss. So, it is quite crucial to measure, in these tubers, both disease severity and incidence (Czajkowski et al. 2011).

The application of plant resistance elicitors, as a complementary option to trigger preventive defense reactions, might aid in controlling the disease; however, this control strategy is not a top priority, since plants lack highly efficient defense elicitors (Deravel et al. 2014). Using chemical resistance, inducer technique has been proved effective in controlling $P$. carotovorum and other bacterial species, which cause soft rot disease (Farrar et al. 2009). Bokshi et al. (2003) showed that acetyl-salicylic acid (ASA) enhanced resistance against $E$. carotovora subsp. carotovora which causes the disease.

In addition, there are other compounds that can inhibit plant pathogens and/or suppress toxin production by pathogens, for example, organic and inorganic salts (Olivier et al. 1998). Benzoic acid and sodium benzoate at the rates of $1.0,5.0$, and $10.0 \mathrm{mM}$, as reported by Saleh and Huang (1997), relatively minimized soft rot disease infection. Acetic and boric acid and bleaching powder are also effective against onion soft rot, Burkholderia cepacia (Rahman et al. 2013). Some essential oils and hemp flower water extract were tested against Erwinia carotovora, a potato bacterial pathogen (Krebs and Jaggir 1999). Simeon and Abubakar (2014) recommended aqueous extracts of each of the lemon grass (Cymbopogon schoenanthus), Aloe vera (Arabian peninsula), and neem (Azadirachta indica), as well as borax salt, as all had inhibitory effects on Pectobacterium spp. and could be used for managing the tuber soft rot.

This present study aimed to isolate the potato soft rot disease isolates found in Egypt and to identify these isolates through morphological, physiological, and molecular (PCR) techniques, as well as to test some essential oils as natural safe materials to control the disease.

\section{Materials and methods}

Isolation and purification of bacteria associated with softrotted potato tubers

Isolation of the causal bacterium was done to potato tubers (Solanum tuberosum) showing symptoms of the soft rot disease, cultivated in four different farms located in Sinai, Sharqia, Gharbia, and Beheira governorates, Egypt. The infected tuber samples with bacterial lesions were picked and washed with tap water to get rid of adherent soil and then were air-dried. The samples were cut into small slices, with 1-2 cm thickness each; each one was surface-sterilized for $2 \mathrm{~min}$ with $2 \%$ sodium hypochlorite solution, rinsed three times in sterile distilled water, and then dried in-between two sterilized filter papers. Then, each sample was transferred onto nutrient agar medium (NA) plates. The inoculated plates were incubated at $30^{\circ}$ $\mathrm{C}$ for $48 \mathrm{~h}$. Randomly, initiated bacterial colonies were picked and transferred to new NA medium plates for purification (Barker 2005). The resulting bacterial colonies were further purified and sub-cultured repeatedly, until pure cultures were obtained (Yuan et al. 2004).

\section{Identification of the pathogenic bacteria Morphological, nutritional, and physiological identification}

A primary identification of the bacterial isolates was conducted on the bases of their morphological, nutritional, and physiological characteristics according to the schemes suggested by Murray and Holt (2001).

\section{Preparation of bacterial inoculum}

Under laboratory conditions, bacterial suspensions of the aforementioned purified bacterial isolates were prepared as described by Desender et al. (2006) with some modifications. Each of the tested bacterial isolate was grown in and sub-cultured on King's B medium for $24 \mathrm{~h}$ at $30^{\circ} \mathrm{C}$ and then suspended in sterile distilled water and centrifuged at $3000 \mathrm{rpm} / \mathrm{min}$ for $30 \mathrm{~min}$. The pellets were re-suspended in distilled water and adjusted turbidimetrically (O.D. at $580 \mathrm{~nm}$ ) to approximately the density of $10^{8} \mathrm{CFU} / \mathrm{ml}$, using a spectrophotometer. The bacterial concentration was estimated from O.D $D_{580}$ data using a standard curve.

\section{Pathogenicity test}

Potato tubers had been flame antisepticised prior to cutting into 1 -cm-thick slices using a sterile knife. Each slice was placed on a moistened sterilized filter paper in a Petri dish. A volume of $0.50 \mathrm{ml}$ of bacterium inoculum of each isolate was pipetted into the center of the five slices to induce artificial infection. Distilled water was used as the control treatment. All treatments were incubated at $30^{\circ} \mathrm{C}$ for 4 days, then pathogenicity was examined on a daily basis. According to Lelliott and Stead (1987) disease infection ranking of rotted potato slices was recorded on a scale of negative $(-)$, low $(+)$, moderate $(++)$, and high $(+++)$ infection. 


\section{Host range}

Tubers, fruits, bulbs, and corms, for 30 different host plants, were inoculated with each of the 10 tested bacterial isolates. Equal slices of each tested plant material were inoculated with $0.5 \mathrm{ml}$ of each isolate at a rate of $10^{8} \mathrm{CFU} \mathrm{m}{ }^{-1}$ by pipetting into the center of each of five slices. For the control, sterilized water was pipetted as well into the center of five slices. Disease rating, as explained, was measured following all treatment incubation at $30^{\circ} \mathrm{C}$ for a 4-day period.

\section{Molecular identification of the pathogenic bacteria DNA extraction}

DNA was extracted from 24-h-old pure bacterial cultures of 12 bacterial isolates grown on NA medium at $37^{\circ} \mathrm{C}$. These isolates were primarily identified as $P$. carotovorum $(P c)$. Pure bacterial colonies were picked by a sterile loop and mixed in $4 \mathrm{ml}$ of nutrient broth media in a sterile labeled culture tubes (Velp, Italy) and incubated overnight at $37^{\circ} \mathrm{C}$, with shaking at $150 \mathrm{rpm}$.

DNA was extracted, using DNeasy Blood and Tissue Kit (Qiagen, China). The protocol was performed according to the manufacturer's instructions. The quantity and quality of the extracted DNA were measured, using the UV-spectrophotometer (T80 plus, PG Instruments Limited, England), and DNA was visualized by electrophoresis (Cleaver, power PAC300) in 1\% agarose gel in 1X Tris-Acetate-EDTA (TAE) (Promega, Madison, Wisconsin) buffer stained with ethidium bromide $(0.5 \mu \mathrm{g} /$ $\mathrm{ml}$ ) (Sambrook 2001). The DNA was stored at $-20^{\circ} \mathrm{C}$ for further PCR work.

The primers used in this study were synthesized by Thermo Fisher Scientific Inc., as described by Yuan et al. (2004).

The PCR specific primers (Fs1: CAGAGTTTGATCCT GGCTCAG) and (Rs1: AAGGAGGTGATCCAGCC) used herein were designed based on the region of the $16 \mathrm{~S}$ ribosomal RNA gene of $P$. carotovorum subsp. carotovorum (Pcc) strain Y46 (Acc. No. KP187511.1). The primers amplified a 220 to 272-bp PCR amplicon unique to $P$. carotovorum, compared to all known DNA sequences in the available databases, and showed homology only to $P$. carotovorum subsp. carotovorum.

DNA amplification was performed according to the non-conventional method (De-Boer and Ward 1995), and the PCR reaction mix $(25 \mu \mathrm{l})$ contained $5.0 \mu \mathrm{l} 5 \mathrm{X}$ Crimson Taq buffer, $1.1 \mu \mathrm{l} 25 \mathrm{mM} \mathrm{MgCl}, 0.5 \mu \mathrm{l} 10 \mathrm{mM}$ dNTPs, $0.13 \mu \mathrm{l} 5 \mathrm{U} / \mu \mathrm{l}$ Taq polymerase, $1.25 \mu \mathrm{l} 10 \mu \mathrm{M}$ of each primer, and $2.0 \mu \mathrm{l}$ DNA template finalized to $25 \mu \mathrm{l}$ by adding 13.77 NFW. PCR was performed in a thermal cycler TProfessional (Biometra, Germany) using the following protocol: denaturation $\left(94^{\circ} \mathrm{C}, 5\right.$ min), followed by 35 cycles of denaturation $\left(94^{\circ} \mathrm{C}, 1\right.$ min), annealing $\left(55^{\circ} \mathrm{C}, 1 \mathrm{~min}\right)$, and extension $\left(72{ }^{\circ} \mathrm{C}\right.$, $1 \mathrm{~min})$ with a final extension $\left(72^{\circ} \mathrm{C}, 7 \mathrm{~min}\right)$, and adjusted as needed.

\section{DNA sequencing and phylogenetic analysis}

PCR product was recognized, and nucleotide sequencing was performed in each direction by Macrogen Korea (Seoul, Rep. of Korea). The similarity search of the PCR product was performed with a Basic local alignment searching tool (BLAST) at the NCBI server (http://blast.ncbi.nlm.nih.gov/Blast.cgi). A Blast search was performed for nucleotide, using BLASTn. Biological evolutionary trees for the data were reconstructed, using MEGA (Kumar et al. 2001), using the Neighbor-Joining (NJ) method.

\section{In vitro antibacterial assay of tested essential oils}

Antibacterial activity was in vitro assayed for the three most virulent $P$. carotovorum isolates Pcc1, Pcc5, and Pcc10 (the causal pathogen of potato tubers rot) for two essential oils, two antibiotics, and three fungicides, as well as for a systematic fungicide. The two oils were (peppermint, Mentha piperita, and clove, Syzygium aromaticum) each at a rate of $1.5,3.0$, and $5.0 \%\left(\mathrm{vv}^{-1}\right)$. The two antibiotics were tetracycline and erythromycin, using rates of 100,200 , and $500 \mathrm{ppm}$ for each. The two fungicides were Galben- $\mathrm{Cu}$ (Benallxyl $\mathrm{Cu} 54 \% \mathrm{WP}$ ) and Copper oxychloride (48\% WP), using rates of 250,500 , and $750 \mathrm{ppm}$ for each. In addition to the above, the systematic fungicide $\mathrm{Tango}^{\circ} 23 \%$ (copper sulfate $8 \%+$ sulfur $28 \%$ ) was tested. All treatments were tested using nutrient agar (NA) plates. For the control treatment, paper disks were immersed in distilled water. For all treatments, the NA plates were inoculated with $0.5 \mathrm{ml}$ of the tested pathogenic bacterial suspension of $10^{8} \mathrm{CFU}$ dilution for $24 \mathrm{~h}$. For each bacterial isolate, four $5-\mathrm{mm}$ filter paper disks, for each treatment, were placed onto the surface of each inoculated plate and later on all plates were incubated at $28^{\circ} \mathrm{C}$ for $72 \mathrm{~h}$. Within the inhibition zone surrounding disks, the bacterial growth was an indication of treatment effect (Fatmi and Schaad 1988).

\section{In vivo antibacterial assay of tested essential oils in potato tubers}

Seven treatments were tested in this experiment using the concentration which gave the highest inhibition zone; two essential oils (peppermint and clove) each at a rate of $5 \%$, two antibiotics (tetracycline and erythromycin) each at a rate of $500 \mathrm{ppm}$, and three fungicides (Copper oxychloride, Benalaxyl- $\mathrm{Cu}$, and systemic fungicide Tango ${ }^{\circ}$ ) each at a rate of $750 \mathrm{ppm}$. The effects of these materials were relatively compared on the three virulent isolates of bacterial potato tubers' rot (Pcc1, Pcc5, and Pcc10 as mentioned above). Five potato tubers 
cv. Spunta, previously inoculated with the pathogenic strains, were treated with each treatment in a completely randomized design $(\mathrm{CRD})$. Nine $(30 \times 40 \times 10 \mathrm{~cm})$ boxes were used. In the first three-box set, each box contained five tubers treated with each of the two essential oils. In the second set, five tubers were treated with each of the two antibiotics. In the last set, five tubers were treated with the three fungicides. In addition to another five inoculated tubers used as controls. All boxes incubated at $28 \pm 2{ }^{\circ} \mathrm{C}$ where soft rot disease severity was estimated after 2 and 4 days based on a $0-5$ ranking scale (Bdliya and Langerfeld 2005) where $0=$ no symptom, $1=1-$ $15 \%$ rotten tuber, $2=16-30 \%, 3=31-45 \%, 4=46-60 \%$, and $5 \geq 61 \%$. The severity was then computed, using the following formula:

$$
\text { Disease Severity }=\frac{\sum n v}{5 N} \times 100
$$

where $n=$ number of infected tubers in each category, $v=$ numerical values of each category, $N=$ total number of the infected tuber, and $5=$ highest score on the severity scale.

\section{Results and discussion}

\section{Frequency of the isolated bacteria from potato tubers} showing soft rot symptoms

Isolation trials from potato tubers showing bacterial soft rot, collected from Sinai, Sharqia, Gharbia, and Beheria governorates, yielded 42 bacterial isolates. The isolates were distributed among five species, belonging to four genera grouped as Pectobacterium sp., Bacillus sp., Dickeya sp., Pseudomonas sp. (1), and Pseudomonas sp. (2) at the frequency of $(10,13,5,8$, and 6 isolates), respectively. Different governorates did not show much difference in the frequency of the isolated species, being 10,13, 11, and 9 isolates from Sinai, Sharqia, Gharbia, and Beheira, respectively. Van der Wolf and De Boer (2007) reported that the main bacteria causing potato tuber soft rot were Pectobacterium atrosepticum, P. carotovorum subsp. carotovorum, and Dickeya spp. (Table 1). Potato seed lots were tested for the soft rot pathogen and found impure with Dickeya spp. and $P$. carotovorum subsp. carotovorum, but not with $P$. atrosepticum. High concentrations of both Dickeya spp. and Pcc were found in the stolon ends, whereas relatively low densities were found in the peel and in deeper located potato tissue (Czajkowski et al. 2009). Pseudomonas syringae van Hall was found only as a species of Gramnegative bacteria isolated from rotted potatoes, collected from clamps in England in 1945-1947 (Jones and Dowson 1950). The isolates of Bacillus spp. are thought to be saprophytic rather than pathogenic, as Bacilli are not formerly reported to be the primary causal agents of soft rots. Lund and Wyatt (1979) highlighted that potato tubers may harbor pectolytic saprophytic bacteria (Bacillus spp., Clostridium spp., Flavobacterium spp., and Pseudomonas spp.) which, if given the opportunity, can also cause rotting.

\section{Pathogenicity and host range of isolated bacteria}

The pathogenicity of obtained isolates was examined on diverse plant hosts (Table 2). Results showed that each of the tested isolates was pathogenic on potato tubers. Out of them, solely three isolates $(1,5$, and 10$)$ caused extremely severe symptoms of soft rot on potato tubers; meanwhile, isolates $2,3,7,8$, and 9 showed moderate severity and isolates 4 and 6 showed low severity on potato tubers once tested for their pathogenicity. On the other hand, on all tested host plants, except sugar beet, isolates 1,5 , and 10 were extremely pathogenic, while isolates $2,3,4,6,7$, and 8 showed low to moderate severity.

Obtained results indicate that there was a correlation between the host plant and the disease severity of some bacterial isolates as potato tubers were highly vulnerable to $P c c 1, P c c 5$, and $P c c 10$ and squash fruits were lowly vulnerable to most isolates, while sugar beet was not vulnerable to the majority of them. The present results are in harmony with those reported by Frampton et al. (2012) who confirmed that $P$. carotovorum was the main causal agent of soft rot disease on potato tubers.

Table 1 Frequency of the isolated bacteria from potato tubers showing soft rot collected from four governorates

\begin{tabular}{|c|c|c|c|c|c|c|}
\hline \multirow{2}{*}{$\begin{array}{l}\text { The isolated } \\
\text { bacteria }\end{array}$} & \multicolumn{4}{|c|}{ Frequency of the isolated bacteria } & \multirow[t]{2}{*}{ Total } & \multirow{2}{*}{$\begin{array}{l}\% \\
\text { Frequency }\end{array}$} \\
\hline & Sinia & Sharqia & Gharbia & $\overline{\text { Beheira }}$ & & \\
\hline Pectobacterium sp. & 2 & 3 & 3 & 2 & 10 & 23.8 \\
\hline Bacillus sp. & 3 & 4 & 3 & 3 & 13 & 30.9 \\
\hline Dickeya sp. & 2 & 2 & 1 & 2 & 7 & 11.9 \\
\hline Pseudomonas sp. (1) & 3 & 3 & 2 & 1 & 9 & 19.1 \\
\hline Pseudomonas sp. (2) & 2 & 1 & 2 & 1 & 6 & 14.2 \\
\hline Total & 12 & 13 & 11 & 9 & 42 & \\
\hline
\end{tabular}


Table 2 Severity of soft rot caused by confirmed isolates of Pectobacterium carotovorum on different hosts

\begin{tabular}{|c|c|c|c|c|c|c|c|c|c|c|c|}
\hline \multirow[t]{2}{*}{ Host species } & \multirow[t]{2}{*}{ Organ } & \multicolumn{10}{|c|}{ Bacterial isolates } \\
\hline & & 1 & 2 & 3 & 4 & 5 & 6 & 7 & 8 & 9 & 10 \\
\hline Potato (Solanum tuberosum) & Tuber & +++ & ++ & ++ & + & +++ & + & ++ & ++ & ++ & +++ \\
\hline Sweet potato (Ipomoea patats) & Root & +++ & + & ++ & ++ & +++ & ++ & ++ & + & ++ & +++ \\
\hline Carrot (Dacus carrot) & Root & +++ & + & + & ++ & +++ & + & ++ & ++ & ++ & +++ \\
\hline Squash (Cucurbita pepo) & Fruit & +++ & + & ++ & + & +++ & + & + & + & ++ & +++ \\
\hline Sugar beet (Beta vulgaris) & Root & + & - & - & - & + & - & - & - & - & + \\
\hline
\end{tabular}

Severity of soft rot symptoms was assessed visually according to Lelliott and Stead (1987) as follows: (-) negative infection, (+) low infection, (++) moderate infection, and (+++) high infection

\section{Identification of isolated bacteria} Morphological, physiological, and biochemical identification Morphological, physiological, and biochemical assays by traditional identification of the 10 strains of the presumptive pathogen Pectobacterium spp. isolates confirmed that all of them were $P$. carotovorum, as they showed the following features: creamy, short rods, and Gram negative, and did not have the ability to produce any pigment in Kings $\mathrm{B}$ medium. All the tested isolates were positive for motility, starch hydrolysis, growth at $37^{\circ} \mathrm{C}$, growth in $5 \% \mathrm{NaCl}$ and $7 \%$ $\mathrm{NaCl}$, catalase activity, pectate degradation, fried egg in PDA, and relation $\mathrm{O}_{2}$ but negative for $\mathrm{KOH} 3 \%$ and pigment production. The strains also induced typical bacterial soft rot symptoms on tuber slices of cv. Spunta (Table 3).

\section{Molecular identification of the pathogenic isolates Detection of bacterial 16S rRNA gene}

Amplifications with the $\mathrm{Fs}_{1}$ and $\mathrm{Rs}_{1}$ primers were positive in all strains also the $\mathrm{Fs}_{1}$ and $\mathrm{Rs}_{1}$ primers discovered $P$. carotovorum subsp. carotovorum DNA in the 10 tested strains (Fig. 1). A sequence similarity was undertaken by using the Blast server at the $\mathrm{Na}$ tional Center for Biotechnology Information. It was found that PCR product was 220-272 bp long, the same size as the region on the $P$. carotovorum subsp. carotovorum 16S rRNA gene between the two primers. An alignment of the nucleotide sequence of the eventual PCR product and the region confined with the two primers of the $P$. carotovorum $16 \mathrm{~S}$ rRNA gene showed an exact size and typical sequence match. Results presented in Table 4 showed the

Table 3 Morphological, physiological, and biochemical characters of isolated bacteria (Pectobacterium sp.)

\begin{tabular}{|c|c|c|c|c|c|c|c|c|c|c|}
\hline Identification tests & 1 & 2 & 3 & 4 & 5 & 6 & 7 & 8 & 9 & 10 \\
\hline Gram reaction & - & - & - & - & - & - & - & - & - & - \\
\hline $\mathrm{KOH} 3 \%$ & - & - & - & - & - & - & - & - & - & - \\
\hline Shape & $\mathrm{R}$ & $\mathrm{R}$ & $\mathrm{R}$ & $\mathrm{R}$ & $\mathrm{R}$ & $\mathrm{R}$ & $\mathrm{R}$ & $\mathrm{R}$ & $\mathrm{R}$ & $\mathrm{R}$ \\
\hline Size & $S$ & $S$ & S & $S$ & $S$ & S & $S$ & $S$ & S & S \\
\hline Motility & + & + & + & + & + & + & + & + & + & + \\
\hline Growth $37^{\circ} \mathrm{C}$ & + & + & + & + & + & + & + & + & + & + \\
\hline Starch hydrolysis & + & + & + & + & + & + & + & + & + & + \\
\hline Tolerance NACL 5\% & + & + & + & + & + & + & + & + & + & + \\
\hline Tolerance NACL 7\% & + & + & + & + & + & + & + & + & + & + \\
\hline Catalase activity & + & + & + & + & + & + & + & + & + & + \\
\hline Pigment production & - & - & - & - & - & - & - & - & - & - \\
\hline Pectate degradation & + & + & + & + & + & + & + & + & + & + \\
\hline Sucrose reduction & - & - & - & - & - & - & - & - & - & - \\
\hline Fried egg in PDA & + & + & + & + & + & + & + & + & + & + \\
\hline Relation $\mathrm{O}_{2}$ & An. & An. & An. & An. & An. & An. & An. & An. & An. & An. \\
\hline Gelatin liquefaction & + & + & + & + & + & + & + & + & + & + \\
\hline Acid prod. gas lactose & + & + & + & + & + & + & + & + & + & + \\
\hline Acid prod. gas glucose & + & + & + & + & + & + & + & + & + & + \\
\hline Name & Pcc1 & Pcc2 & Pсc3 & Pcc4 & Pcc5 & Pcc6 & Pcc7 & Pcc8 & Pcc9 & Pcc10 \\
\hline
\end{tabular}




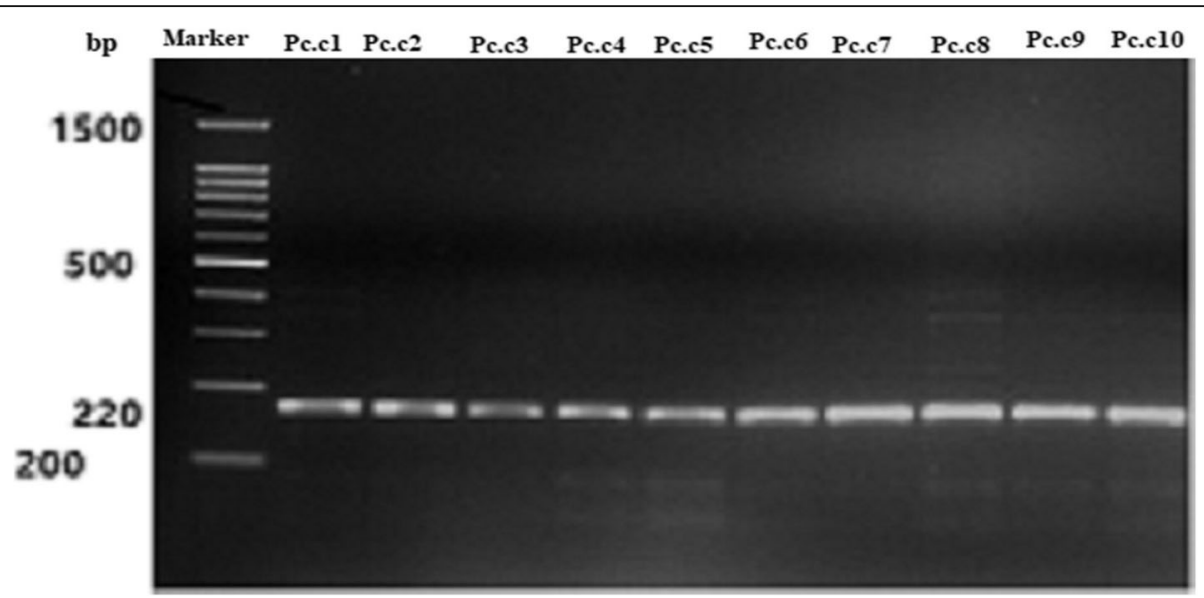

Fig. 1 PCR amplified DNA in 10 indigenous isolates of Pectobacterium carotovorum (PCC), using Fs1 and Rs1 primers

sequence of this $210-250 \mathrm{bp}$ PCR amplicon. The latter PCR amplicon was obtained by the phenotypically identified $P$. carotovorum subsp. carotovorum strains only, but in the other examined strains, the PCR products were not observed. These results agree with those obtained by Weisburg et al. (1991) who reported that for definitive identification of $P$. carotovorum strains, $16 \mathrm{~S}$ rRNA gene analysis was carried out, using two PCR primers for the specific $16 \mathrm{~S}$ rRNA gene of $P$. carotovorum (GenBank Accession No. KP187511.1). The obtained nucleotide sequence of the 16S rRNA PCR product was in alignment with that of $P$. carotovorum $16 \mathrm{~S}$ rRNA gene sequence. These results are in harmony with those obtained by Toth et al. (2001) who proved that the 16SrRNA analysis was used to identify the isolated bacterial strains at the molecular level. Yap et al. (2004) had similar results and identified a single amplicon produced by specific primers; however, Zhu et al. (2010) obtained four amplicons produced by the designed $16 \mathrm{~S}$ rRNA gene primers.

\section{Phylogenetic analysis}

Searching nucleotide database, using a nucleotide query (BLASTn) of all isolates' sequences, obtained from 10 isolates that amplified with Fs1 and Rs1 set of primers, showed a high similarity with different strains of $P c c$ deposited in the GenBank (Accession No. KP187511.1). The nucleotide sequence similarity percentage ranged from 87 to $98 \%$, which confirms a variation among the 10 isolates (Fig. 2a-d).

Isolates Pcc1, Pcc2, Pcc3, and Pcc4 clustered closely to reference strains Y46 (Acc. No. KP187511.1) with 87 to 99\% bootstrap value, whereas isolates Pcc6 and Pcc8 clustered individually and were closer to the $P c c$ strain Y46 (Acc. No. KP187511.1) with 100\% bootstrap value. Moreover, isolates Pcc5 and Pcc7 clustered to the reference strain Y46 (Acc. No. CP001657.1) and Erwinia carotovorum (Acc. No. KP405846.1) with 90 to $92 \%$ and 95 to $99 \%$ bootstrap value, respectively.

In the present study, PCR was carried out for all DNA extracts of bacterial soft rot isolates that were identified by biochemical tests as Pcc. The results of the 10 isolates

Table 4 Homology search (BLAST) results of all sequenced samples

\begin{tabular}{|c|c|c|c|c|c|}
\hline No. & Primer set & Isolate* & No. of bases & $E$ value & Maximum similarity hit \\
\hline 1 & Fs1/Rs1 & Pccl & $250 \mathrm{bp}$ & $5 e-124^{* *}$ & $93-98 \%$ \\
\hline 2 & & Pcc2 & $240 \mathrm{bp}$ & $6 e-92^{* *}$ & $94-98 \%$ \\
\hline 3 & & Pсc3 & $240 \mathrm{bp}$ & $7 e-110^{* *}$ & $87-92 \%$ \\
\hline 4 & & Pcc4 & $238 \mathrm{bp}$ & $7 e-97^{* *}$ & $96-99 \%$ \\
\hline 5 & & Pcc5 & $240 \mathrm{bp}$ & $8 e-109^{* *}$ & $90-92 \%$ \\
\hline 6 & & Рсc6 & $210 \mathrm{bp}$ & $4 e-30^{* *}$ & $99-100 \%$ \\
\hline 7 & & Pcc7 & $210 \mathrm{bp}$ & $1 e-93^{* *}$ & $95-99 \%$ \\
\hline 8 & & Pcc8 & $210 \mathrm{bp}$ & $2 e-104^{* *}$ & $98-99 \%$ \\
\hline Acc. No. KP187511.1 & & Pсc9 & P. carotovorum & $4 e-106$ & $100 \%$ \\
\hline Acc. no. KP405846.1 & & Pcc10 & Erwinia carotovorum & $6 e-16$ & $100 \%$ \\
\hline
\end{tabular}

*The type of product that have been sequenced (PCR products) and ${ }^{* *}$ significance 


\section{a}
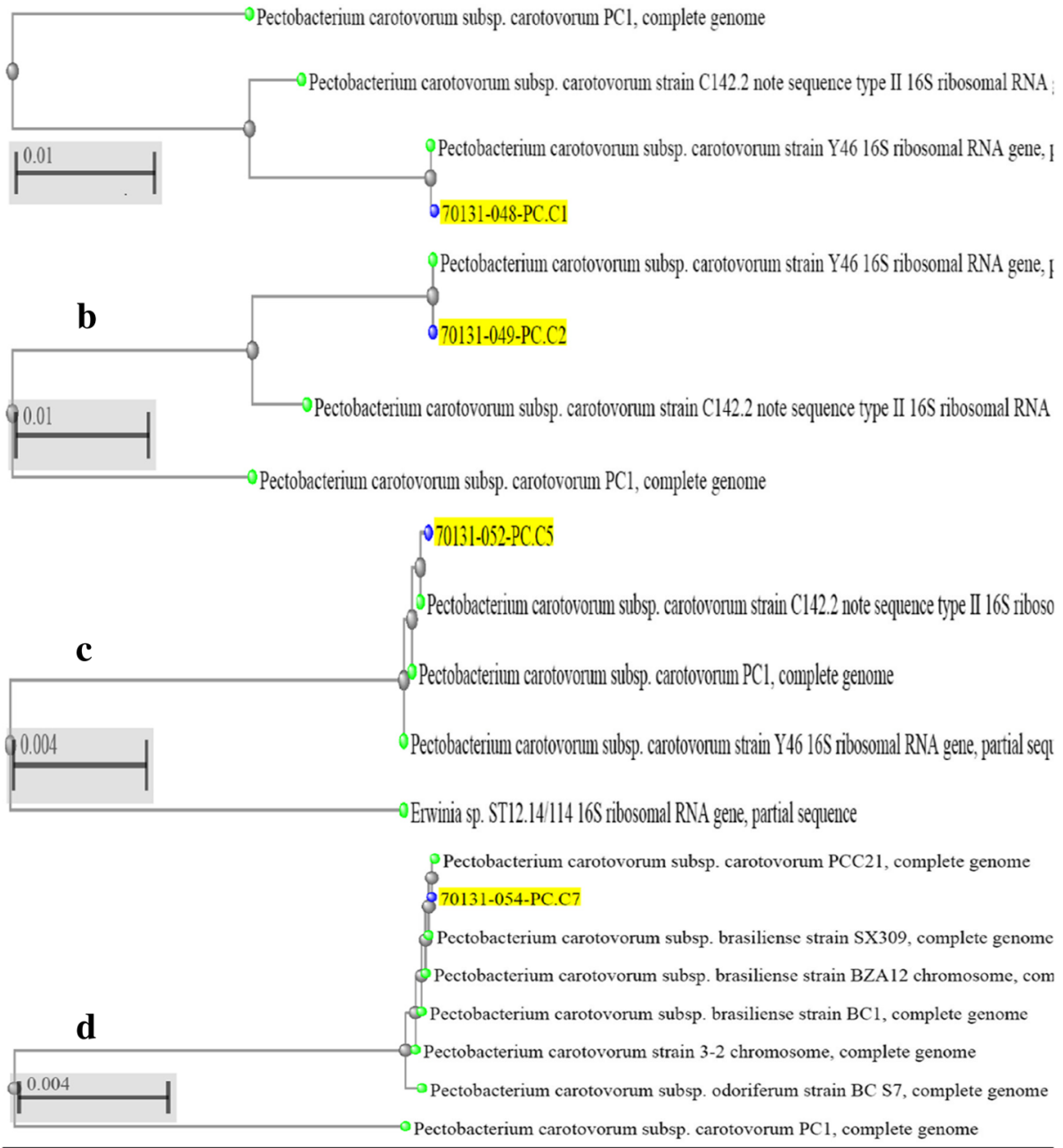

Fig. 2 Phylogenetic analysis of nucleotide sequences of Pectobacterium carotovorum isolates (Pcc) detected, based on sequences of Pc.c1 = 250 $\mathrm{bp}(\mathbf{a}), \mathrm{Pc} . \mathrm{c} 2=240 \mathrm{bp}(\mathbf{b}), \mathrm{Pc} . \mathrm{c} 5=240 \mathrm{bp}(\mathbf{c})$, and Pc.c7 $=210 \mathrm{bp}(\mathbf{d})$ and aligned on different regions of the $16 \mathrm{~S}$ ribosomal gene, with close species. The branching pattern was generated by the Neighbor-Joining method; stability of the tree was assessed by 1000 bootstrap replication

examined detected the presence of the desired DNA fragments of $1530 \mathrm{bp}$, using the $16 \mathrm{~S}$ rDNA set of primers Fs1 and Rs1 resembling the positive DNA extract of the reference strain Pcc Y46 (Acc. No. KP187511.1), which gave a product size of $1530 \mathrm{bp}$. The $16 \mathrm{~S}$ rDNA sequences were conserved with stable copies, and their analysis were characteristic than other ribosomal regions. In general, $16 \mathrm{~S}$ rDNA was amplified and sequenced by universal primers to identify species and subspecies (De Boer et al. 2012).

In the homology search, BLASTn of Pcc isolates sequenced on the bases of the 16S rDNA showed high similarity, with diverse reference strains at the GenBank (Acc. No. KP187511.1 and Acc. No. KP405846.1) that were closely related to the sequences of other bacterial rotting causal agents such as Pseudomonas spp., Bacillus spp., Serratia spp., and Enterobacter spp. In fact, the Fs1 and Rs1 primers that were used in the study were general primers, which can detect different bacterial causal agents (Shrihari and Negi 2011) and could be used as an exploratory step in bacterial identification.

In the majority of the cases, genotypic isolates were more carefully related than those isolated from different geographical regions. However, the similarity among the groups of isolates separated from several regions suggested the same genetic origin of these isolates.

Soft rot disease is widely common in different potato-growing areas in Egypt, and the results of biochemical and physiological experiments confirmed that the main causative agent of bacterial soft rot in Egypt is P. carotovorum subsp. carotovorum, while using the PCR primer pair Fs1/Rs1 was authoritative in detection and identification of all the soft rot Egyptian isolates of Pcc. DNA sequencing was found to be the most 
reliable way in specific detection and affirmation of the causal agent of soft rot. Furthermore, studies to assay soft rot disease etiology and epidemiology are needed. Compared to diversified DNA sequence analysis, used in this study, biochemical experiments were able to identify most isolates but misidentified others.

\section{Effect of essential oils, antibiotics, and fungicides on the $P$.} carotovorum in vitro

Assays of potential management materials in vitro and in vivo were carried out on the three most virulent isolates of $P c c$ (Pcc1, Pcc5, Pcc10), as confirmed by the pathogenicity test. The different isolates varied in their sensitivity to the examined materials. Notably, there is a positive correlation between the growth inhibition and the concentration increase of all examined materials. At the highest concentrations, most of them positively inhibited the growth of the pathogen (Fig. 3). Peppermint oil showed the greatest inhibitory effect among all the examined materials. Surprisingly, the effect caused by the highest concentration of the nano-copper-based fungicide Tango was worthless. Among the tested antibiotics, tetracycline showed higher inhibitory effect than erythromycin that equals nearly a twofold increase. Preferable control of E. carotovora by erythromycin and tetracycline and partial control with copper compound were also reported by Mills and Hurta (2006).

The antibiotics tetracyclines and oxytetracycline stimulate their bactericidal effect by the inhibition of protein synthesis; present studies also approved the bactericidal efficiency of such chemicals against $P$. carotovorum subsp. carotovorum. Among the examined fungicides, Galben- $\mathrm{Cu}$ was nearly had equal effect as copper oxychloride. Tango showed three- to fourfold decrease in inhibition than the former two fungicides (Fig. 3). Concerning safety, peppermint oil is considered the preferable treatment for controlling Pcc isolates in vitro.

\section{In vivo management trials of Pcc soft rot disease on potato}

The results showed that the effect of the same examined compounds in vivo behaved differently than they did in in vitro assays when tested on the same isolates. The results in Table 5 indicate that percentages of disease severity (DS) and disease incidence (DI) were significantly affected by tested treatments. The disease severity values obtained by peppermint oil reached 0.0 to $6.5 \%$, while the values of disease incidence reached 0.0 to $17.5 \%$, recorded as the highest significant decrease as compared to control and depending on the isolate. Meanwhile, clove oil in this experiment reduced the disease severity and disease incidence significantly to be $0.0 \%$. As for the two antibiotics, tetracycline reduced the disease severity significantly to be $0.0 \%$ as compared to control, which was better than the effect of erythromycin that reached 0.0 to $1.5 \%$ without any significant differences in-between them. In respect of the disease incidence, the same trend was noticed. The tested commonly used copper fungicides equalled in their effect and reduced the soft rot severity ( 0.0 to $1.5 \%$ ) as compared to control. Contrary to its effect in vitro, the nano- $\mathrm{Cu}$ fungicide Tango reduced the disease severity to $0.0 \%$ than in the control. Gakuubi et al. (2016) obtained a strong antibacterial activity with the essential oil of Mexican marigold (Tagetes minuta L.) against bacterial plant pathogens, i.e., P. savastanoi pv. phaseolicola, Xanthomonas axonopodis pv. phaseoli, and X. axonopodis pv. maanihotis. In another study, T. minuta also showed antibacterial activity against $P$. carotovorum in potatoes grown in the field and in storage (Al Abbasy et al. 2015). The antibacterial activity in the essential oils of several medicinal plants has been related to the attack on the phospholipids in the cell membranes of the microbes, which causes

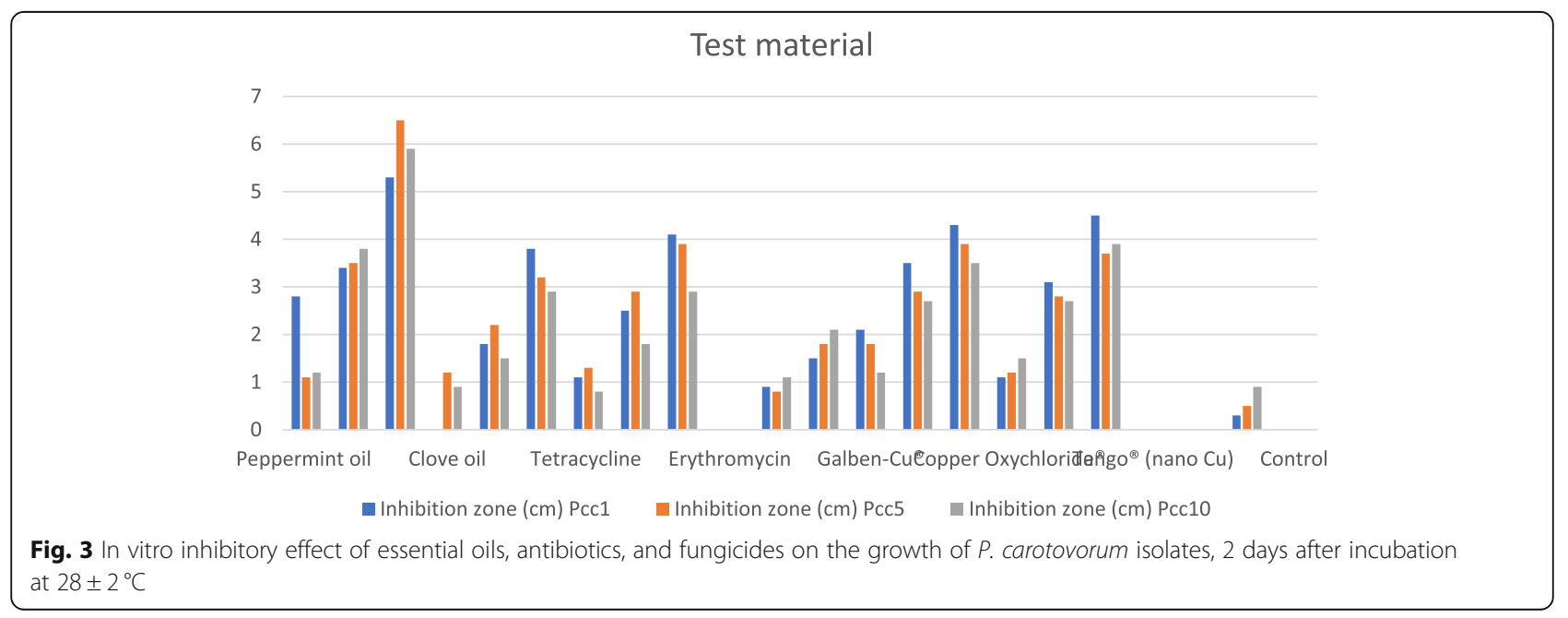


Table 5 Effect of different materials on soft rot severity on potato tubers 2 and 4 days after storage

\begin{tabular}{|c|c|c|c|c|c|c|c|c|c|c|c|c|}
\hline \multirow[t]{3}{*}{ Treatment } & \multicolumn{4}{|l|}{ PCC1 } & \multicolumn{4}{|l|}{ Pcc5 } & \multicolumn{4}{|c|}{ Pcc10 } \\
\hline & \multicolumn{2}{|c|}{2 days } & \multicolumn{2}{|c|}{4 days } & \multicolumn{2}{|c|}{2 days } & \multicolumn{2}{|c|}{4 days } & \multicolumn{2}{|c|}{2 days } & \multicolumn{2}{|c|}{4 days } \\
\hline & $\overline{\mathrm{DS}}$ & $\mathrm{DI}$ & $\overline{D S}$ & $\mathrm{DI}$ & $\overline{D S}$ & $\overline{\mathrm{DI}}$ & $\overline{\mathrm{DS}}$ & $\overline{\mathrm{DI}}$ & $\overline{\mathrm{DS}}$ & $\mathrm{DI}$ & $\overline{\mathrm{DS}}$ & $\mathrm{DI}$ \\
\hline Peppermint oil & 4.5 & 17.5 & 6.5 & 20.5 & 0.0 & 0.0 & 1.5 & 4.7 & 1.5 & 4.7 & 4.5 & 17.5 \\
\hline Clove oil & 0.0 & 0.0 & 0.0 & 0.0 & 0.0 & 0.0 & 0.0 & 0.0 & 0.0 & 0.0 & 0.0 & 0.0 \\
\hline Erythromycin & 0.0 & 0.0 & 1.5 & 4.7 & 0.0 & 0.0 & 1.5 & 4.7 & 0.0 & 0.0 & 1.5 & 4.7 \\
\hline Tetracycline & 0.0 & 0.0 & 0.0 & 0 & 0.0 & 0.0 & 0.0 & 0 & 0.0 & 0.0 & 0.0 & 0.0 \\
\hline Galben-Cu & 0.0 & 0.0 & 1.5 & 4.7 & 0.0 & 0.0 & 1.5 & 4.7 & 0.0 & 0.0 & 1.5 & 4.7 \\
\hline Copper oxychloride & 0.0 & 0.0 & 1.5 & 4.7 & 0.0 & 0.0 & 1.5 & 4.7 & 0.0 & 0.0 & 1.5 & 4.7 \\
\hline Tango & 0.0 & 0.0 & 0.0 & 0.0 & 0.0 & 0.0 & 0.0 & 0.0 & 0.0 & 0.0 & 0.0 & 0.0 \\
\hline Control & 27.9 & 53.3 & 65.5 & 86.7 & 37.8 & 60 & 61.3 & 80 & 33.8 & 66.7 & 67.7 & 93.3 \\
\hline
\end{tabular}

DS disease severity\%, DI disease incidence $\%$

increased permeability and leakage of cytoplasm thereby killing the bacteria.

\section{Conclusions}

Studies of 10 isolates of $P$. carotovorum (soft rot) showed pathogenicity to potato tubers and other hosts. P. carotovorum, in the reference strain Pcc Y46 in PCR experiments and the sequencing that followed, revealed that all the isolates yielded 220-272-bp DNA fragments identical to the 16S rRNA gene of Pcc Y46. Potential management against the disease was evaluated by testing two essential oils, i.e., peppermint and clove, and a nano- $\mathrm{Cu}$-based fungicide, i.e., Tango, which were compared to two different antibiotics and two different commonly used copper fungicides. In vitro assays, peppermint oil at the highest tested concentration was the best treatment, giving higher inhibition zones than the antibiotics and copper fungicides. PCR-based assay made it easy and accurate to identify Egyptian isolates of the soft rot causative agent $P$. carotovorum subsp. carotovorum from diseased potato tubers. Clove essential oil was a new safe material for the management of soft rot disease of potato tubers in storage.

\section{Acknowledgements}

The authors would like to thank Dr. Eman O. Hassan, Assoc. Prof. of Plant Pathol., Plant Pathol. Dept., Fac. of Agric. at Moshtohor, Benha Univ., Egypt, Sincere thanks are also given to Moshtohor Research Park, Molecular Biology Lab., Benha Univ., Egypt.

\section{Funding}

Not applicable for this section.

Availability of data and materials

Not applicable for this section.

\section{Authors' contributions}

All authors equally contributed in all the article parts. All authors read and approved the final manuscript.

Ethics approval and consent to participate

Not applicable for this section.
Consent for publication

Not applicable for this section.

Competing interests

The authors declare that they have no competing interests.

\section{Publisher's Note}

Springer Nature remains neutral with regard to jurisdictional claims in published maps and institutional affiliations.

\section{Author details}

${ }^{1}$ Plant Pathology Department, Faculty of Agriculture at Moshtohor, Benha University, Moshtohor, Tukh, Qalubia 13736, Egypt. ${ }^{2}$ Genetics and Genetic Engineering Department, Faculty of Agriculture at Moshtohor, Benha University, Moshtohor, Tukh, Qalubia 13736, Egypt. ${ }^{3}$ Moshtohor Research Park, Molecular Biology Lab, Benha University, Tukh, Qalubia 13736, Egypt.

Received: 17 August 2018 Accepted: 3 January 2019

Published online: 29 January 2019

\section{References}

Al Abbasy DW, Pathare N, Al-Sabahi JN, Khan SA (2015) Chemical composition and antibacterial activity of essential oil isolated from Omani basil (Ocimum basilicum Linn.). Asian Pac J Trop Dis 5(8):645-649

Avrova AO, Hyman LJ, Toth RL, Toth IK (2002) Application of amplified fragment length polymorphism fingerprinting for taxonomy and identification of the soft rot bacteria Erwinia carotovora and Erwinia chrysanthemi. Appl Environ Microbiol 68(4):1499-1508

Barker K (2005) At the Bench: A laboratory navigator, Update Edition. Cold Spring Harbor Laboratory Press. Cold Spring Harbor, New York

Bdliya B, Langerfeld E (2005) A semi-selective medium for detection, isolation and enumeration of Erwinia carotovora ssp. carotovora from plant materials and soil. Trop Sci 45(2):90-96

Bokshi A, Morris S, Deverall B (2003) Effects of benzothiadiazole and acetylsalicylic acid on $\beta$-1, 3-glucanase activity and disease resistance in potato. Plant Pathol 52(1):22-27

Crépin A, Barbey C, Cirou A, Tannières M, Orange N, Feuilloley M, Dessaux Y, Burini J-F, Faure D, Latour X (2012) Biological control of pathogen communication in the rhizosphere: a novel approach applied to potato soft rot due to Pectobacterium atrosepticum. Plant Soil 358(1-2):27-37

Czajkowski R, Grabe GJ, van der Wolf JM (2009) Distribution of Dickeya spp. and Pectobacterium carotovorum subsp. carotovorum in naturally infected seed potatoes. Eur J Plant Pathol 125(2):263-275

Czajkowski R, Perombelon MC, van Veen JA, van der Wolf JM (2011) Control of blackleg and tuber soft rot of potato caused by Pectobacterium and Dickeya species: a review. Plant Pathol 60(6):999-1013

De Boer S, Li X, Ward L (2012) Pectobacterium spp. associated with bacterial stem rot syndrome of potato in Canada. Phytopathology 102(10):937-947 
De-Boer SH, Ward J (1995) PCR detection of Erwinia carotovora subsp. atroseptica associated with potato tissue. Phytopathology 85:854-858

Deravel J, Krier F, Jacques P (2014) Biopesticides, a complementary and alternative approach to the use of agrochemicals. A review Biotechnologie, Agronomie, Société et Environnement 18(2):220-232

Desender S, Klarzynski O, Potin P, Barzic MR, Andrivon D, Val F (2006) Lipopolysaccharides of Pectobacterium atrosepticum and Pseudomonas corrugata induce different defence response patterns in tobacco, tomato, and potato. Plant Biol 8(5):636-645

Douches D, Maas D, Jastrzebski K, Chase R (1996) Assessment of potato breeding progress in the USA over the last century. Crop Sci 36(6):1544-1552

FAO (2016) International Year of the Potato. Food and Agriculture Organization of the United Nations (FAO). http://www.fao.org/faostat/en/\#data/QC

Farrar J, Nunez J, Davis R (2009) Losses due to lenticel rot are an increasing concern for Kern County potato growers. Calif Agric 63(3):127-130

Fatmi M, Schaad N (1988) Semiselective agar medium for isolation of Clavibacter michiganense subsp. michiganense from tomato seed. Phytopathology 78(1): $121-126$

Frampton RA, Pitman AR, Fineran PC (2012) Advances in bacteriophage-mediated control of plant pathogens. Int J Microbiol 2012:1-11

Gakuubi MM, Wanzala W, Wagacha JM, Dossaji SF (2016) Bioactive properties of Tagetes minuta L.(Asteraceae) essential oils: a review. Am J Essent Oils Nat Products 4(2):27-36

Gardan L, Gouy C, Christen R, Rg S (2003) Elevation of three subspecies of Pectobacterium carotovorum to species level: Pectobacterium atrosepticum sp. nov., Pectobacterium betavasculorum sp. nov. and Pectobacterium wasabiae sp. nov. Int J Syst Evol Microbiol 53(2):381-391

Jones DR, Dowson WJ (1950) On the bacteria responsible for soft rot in stored potatoes, and the reaction of the tuber to invasion by Bacterium carotovorum (Jones) Lehmann \& Neumann. Ann Appl Biol 37(4):563-569

Krebs H, Jaggir W (1999) Effect of plant extracts against soft rot of potatoes: Erwiniacarotovora Flora and Fauna $n$ industrial crops. Agrarforschung 6(1):17-20

Kumar S, Tamura K, Jakobsen IB, Nei M (2001) MEGA2: molecular evolutionary genetics analysis software. Bioinformatics 17(12):1244-1245

Lelliott RA, Stead DE (1987) Methods for the Diagnosis of Bacterial Diseases of Plants. Blackwell Scientific Publications, Oxford. p. 216

Lund BM, Wyatt G (1979) A method of testing the effect of antibacterial compounds on bacterial soft rot of potatoes, and results for preparations of dichlorophen and sodium hypochlorite. Potato Res 22(3):191-202

Ma B, Hibbing ME, Kim H-S, Reedy RM, Yedidia I, Breuer J, Breuer J, Glasner JD, Perna NT, Kelman A (2007) Host range and molecular phylogenies of the soft rot enterobacterial genera Pectobacterium and Dickeya. Phytopathology 97(9):1150-1163

Mills A, Hurta R (2006) Sensitivity of Erwinia spp. to salt compounds in vitro and their effect on the development of soft rot in potato tubers in storage. Postharvest Biol Technol 41(2):208-214

Murray RGE, Holt JG (2001) The History of Bergey's Manual. In: Boone DR Castenholz RW, Garrity GM, editors. Bergey's Manual ${ }^{\circledR}$ of Systematic Bacteriology. Springer, New York

Nabhan S, Wydra K, Linde M, Debener T (2011) The use of two complementary DNA assays, AFLP and MLSA, for epidemic and phylogenetic studies of pectolytic enterobacterial strains with focus on the heterogeneous species Pectobacterium carotovorum. Plant Pathol 61(3):498-508

Olivier C, Halseth DE, Mizubuti ES, Loria R (1998) Postharvest application of organic and inorganic salts for suppression of silver scurf on potato tubers. Plant Dis 82(2):213-217

Perombelon MC, Kelman A (1980) Ecology of the soft-rot Erwinias. Annu Rev Phytopathol 18(1):361-387

Rahman MM, Khan AA, Akanda AM, Mian IH, Alam MZ (2013) Chemical control of bacterial soft rot of onion. Bangladesh J Plant Patholol 29(1\&2):1-4

Saleh O, Huang J (1997) Bacterial soft rot disease of tomato fruits in Florida, USA: identification, response of some American and Egyptian cultivars of solanaceous plants and chemical control. Assiut J Agric Sci 28(2):11-26

Sambrook J RD (2001) Rapid isolation of yeast DNA. In: DW SJR (ed) Molecular Cloning, a Laboratory Manual. New York: Cold Spring Harbor Laboratory Press, pp 631-632

Shrihari RY, Negi PS (2011) Detection, identification and characterization of staphylococci in street vend foods - characterization of staphylococcus isolates. Food Nutr Sci 2(4):304-313
Simeon AU, Abubakar A (2014) Evaluation of some plant extracts for the control of bacterial soft rot of tubers. Am J Exp Agric 4(12):1869-1876

Toth I, Avrova A, Hyman L (2001) Rapid identification and differentiation of the soft rot Erwinias by $16 \mathrm{~S}-23 \mathrm{~S}$ intergenic transcribed spacer-PCR and restriction fragment length polymorphism analyses. Appl Environ Microbiol 67(9):4070-4076

Van der Wolf J, De Boer S (2007) Bacterial pathogens of potato. In: Vreugdenhil D, Bradshaw J, Gebhardt C et al (eds) Potato biology and biotechnology: advances and perspectives. Elsevier, Oxford, pp 595-619

Weisburg WG, Barns SM, Pelletier DA, Lane DJ (1991) 16 S ribosomal DNA amplification for phylogenetic study. J Bacteriol 173(2):697-703

Yap M-N, Barak JD, Charkowski AO (2004) Genomic diversity of Erwinia carotovora subsp. carotovora and its correlation with virulence. Appl Environ Microbiol 70(5):3013-3023

Yuan F, Qu S, Cui C, Cao MQ, Ma RC (2004) A new strain of Erwinia carotovora subsp. carotovora isolated from soft-rotted Chinese Cabbag. Acta Microbiol Sin 44(2):136-140

Zhu L, Xie H, Chen S, Ma R (2010) Rapid isolation, identification and phylogenetic analysis of Pectobacterium carotovorum ssp. J Plant Pathology 92(2):479-483

\section{Submit your manuscript to a SpringerOpen ${ }^{\circ}$ journal and benefit from:}

- Convenient online submission

- Rigorous peer review

- Open access: articles freely available online

- High visibility within the field

- Retaining the copyright to your article

Submit your next manuscript at $\boldsymbol{\nabla}$ springeropen.com 